\title{
Body Weight, Activities of Cytochrome Oxidase and Electron Transport System in the Liver of the American Plaice Hippoglossoides platessoides. Can these Activities Serve as Indicators of Metabolism?
}

\author{
John Clegg Smith ${ }^{1}$ and Chi Keung Chong ${ }^{2}$ \\ 1 Marine Ecology Laboratory, Ocean Science and Surveys, Department of Fisheries and Oceans, Bedford Institute of \\ Oceanography, P.O. B. 1006, Dartmouth, Nova Scotia B2Y 4A2, Canada \\ 2 Department of Oceanography, Dalhousie University, Halifax, Nova Scotia B3A 4J1, Canada
}

\begin{abstract}
In many organisms, including fish, metabolic rate (oxygen consumption rate, $\dot{\mathrm{V}}_{\mathrm{O}_{2}}$ ) is related to body weight (W) allometrically, that is, by a function of the form $\dot{\mathrm{V}}_{\mathrm{O}_{2}}=a \mathrm{~W}^{b}, \mathrm{~b}$ often taking a value near 0.8. Metabolic oxidation is controlled by a chain of enzymes and cytochromes known as respiratory electron transport system. This paper tests the hypothesis that the activities of the hepatic electron transport system (ETS) and its terminal oxidese (cytochrome oxidase, CYTOX) are related to W by a similar function for a natural population of American plaice Hippoglossoides platessoides. All measures of hepatic ETS and CYTOX activities $\left(K_{1}\right)$ turned out to be significantly related to $W$ by a function of the form $K_{1}=c W^{d}$, where $d=$ rate of change of enzyme activities with W. The values of $d$ for the total hepatic ETS and CYTOX activities are $0.90 \pm 0.03$ (S. E.) and $0.83 \pm 0.04$ (S. E.) respectively. These values are close to 0.8 , the value of the exponent for the $\dot{\mathrm{V}}_{\mathrm{O}_{2}}-\mathrm{W}$ relationship in $H$. platessoides. The possibility that CYTOX and ETS activities might serve as indicators of routine metabolic rate is discussed in relation to a set of criteria proposed.
\end{abstract}

\section{INTRODUCTION}

The basal metabolic or oxygen consumption rate $\left(\mathrm{V}_{\mathrm{O}_{2}}\right)$ is a function of wet body weight (W) to approximately the 0.8 power in many fish (Winberg, 1956; Paloheimo and Dickie, 1966), including the American plaice (MacKinnon, 1972). Thus the weight-specific oxygen consumption rate $\left(\dot{\mathrm{V}}_{\mathrm{O}_{2}} / \mathrm{W}\right)$ decreases with increasing $W$ and is a function of $W^{-0.2}$. The organweight-specific oxygen consumption rate $\left(\mathrm{V}_{\mathrm{O}_{2.1}} / \mathrm{W}_{\mathrm{L}}\right)$ for the liver of the toadfish Opsanus tau (Vernberg, 1954) and the freshwater teleost Etroplus maculatus (Parvatheswararao, 1972) also declines with increasing body weight. Kleiber (1941) found a similar relationship for several species of mammals and showed that the body-weight exponent was practically the same as that for the whole animal. Krebs (1950) obtained similar results for liver in 9 mammalian species but not for the brain, kidney, spleen and lung. The integrative role of liver in metabolism thus seems to be such that its $\dot{V}_{\mathrm{O}_{2}, \mathrm{~L}} / \mathrm{W}_{\mathrm{L}}$ is related to $\mathrm{W}$ in the same fashion as the total body $\dot{\mathrm{V}}_{\mathrm{O}_{2}} / \mathrm{W}$ of the animal.

The electron transport system provides cellular energy in the form of ATP by coupling electron transport through the cytochrome chain with oxidative phosphorylation. Its activity (ETS) and the activity of its terminal oxidase, cytochrome oxidase (CYTOX), have been shown to reflect the oxidative metabolic rates of many tissues and whole organisms from mammals to plankton (Kunkel and Campbell, 1952; Jansky, 1961; Packard, 1971; Simon and Robin, 1971; Kenner and Ahmed, 1975b). In view of this and of the pervasive role of the liver in metabolism, it is likely that these oxidative enzyme activities in fish liver may be related to $\mathrm{W}$ in the same manner as the oxygen consumption rate. Accordingly, the first objective of this 
study was to test this hypothesis in a natural population of the American plaice Hippoglossoides platessoides.

Metabolic rate is an important variable to estimate when studying ecosystem energetics. It is commonly determined as oxygen consumption rate. Unfortunately, current techniques for measuring oxygen consumption rate directly (iodometry, manometry, polarography) involve confinement of the fish (or other organisms) in a respirometer. Besides being cumbersome, time-consuming and providing data at a low rate (in the statistical sense), it seems likely that a consequence of this manipulation would be severe stress of the animal and probably a mis-estimation of the routine metabolic rate exhibited by the fish in its environment. Similar considerations have contributed to numerous attempts to utilize enzyme activities (especially ETS) as indicators of metabolic rate in laboratory and field studies of bacteria, phytoplankton and zooplankton (Packard, 1971; Kenner and Ahmed, 1975a, b; King and Packard, 1975; Owens and King, 1975; Christensen and Packard, 1976; Borgmann, 1978; Devol and Packard, 1978; King et al., 1978; Bamstedt, 1980, Christensen et al., 1980). In view of this it seemed worthwhile to consider what criteria an enzyme must satisfy to serve as a useful metabolic indicator and to examine how well CYTOX and ETS perform in this regard.

\section{MATERIALS AND METHODS}

The following abbreviations are used:

$\mathrm{W}$ body weight $(\mathrm{g}) ; \mathrm{W}_{\mathrm{L}}$ liver weight $(\mathrm{g}) ; \mathrm{W}_{\mathrm{L}} / \mathrm{W}$ weight specific liver weight.

$\dot{V}_{\mathrm{O}_{2}}, \dot{V}_{\mathrm{O}_{2} \text {,max }}, \dot{V}_{\mathrm{O}_{2, \mathrm{r}} \mathrm{rn}}, \dot{V}_{\mathrm{O}_{2} \text { min }}$ oxygen consumption rate or metabolic rate, maximum (active) $\dot{V}_{\mathrm{O}_{2}}$ routine $\dot{V}_{\mathrm{O}_{2}}$ and minimum (standard) $\dot{V}_{\mathrm{O}^{\prime}}$ respectively; $\dot{V}_{\mathrm{O}_{2}} / \mathrm{W}$ weight-specific oxygen consumption rate; $\dot{\mathrm{V}}_{\mathrm{O}_{2}, \mathrm{~L}} / \mathrm{W}_{\mathrm{L}}$ liver-weight specific oxygen consumption rate.

INT 2-(p-iodophenyl)-3-(p-nitrophenyl)-5-phenyl tetrazolium chloride; ATP adenosine triphosphate; NADH reduced form of nicotinamide adenine dinucleotide; NADPH reduced form of nicotinamide adenine dinucleotide phosphate.

$\mathrm{P}_{2}$ hepatic protein concentration ( $\mathrm{g}$ protein $\mathrm{g}^{-1}$ liver); $P_{3}$ total hepatic protein $P_{2} \times W_{L}$ (g protein); $P_{4}$ body-weight specific hepatic protein $\mathrm{P}_{3} / \mathrm{W}$ (g hepatic protein $\mathrm{g}^{-1}$ fish).

CYTOX cytochrome oxidase (cytochrome $\mathrm{C}: \mathrm{O}_{2}$ oxidoreductase, E.C. 1.9.3.1); CYT $_{2}$ liver-weight specific CYTOX activity $\left(\mathrm{s}^{-1} \mathrm{~g}^{-1} \text { liver }\right)_{i} \mathrm{CYT}_{3}$ total hepatic CYTOX activity $\mathrm{CYT}_{2} \times \mathrm{W}_{\mathrm{L}}\left(\mathrm{s}^{-1}\right) ; \mathrm{CYT}_{4}$ bodyweight specific hepatic CYTOX activity $\mathrm{CYT}_{3} / \mathrm{W}\left(\mathrm{s}^{-1}\right.$ $\mathrm{g}^{-1}$ fish); $\mathrm{CYP}_{\mathrm{p}}$ protein specific hepatic CYTOX activity $C Y T_{2} / P_{2}\left(s^{-1} g^{-1}\right.$ hepatic protein).

ETS election transport system activity based on the measurement of the rate of INT reduction (Packard, 1971); $\mathrm{ETS}_{2}$ liver-weight-specific hepatic ETS activity $\left(\mu \mathrm{l} \mathrm{O}_{2} \mathrm{~min}^{-1} \mathrm{~g}^{-1}\right.$ liver); ETS $_{3}$ total hepatic ETS activity $\mathrm{ETS}_{2} \times \mathrm{W}_{\mathrm{L}}\left(\mu \mathrm{l} \mathrm{O}_{2} \mathrm{~min}^{-1}\right) ; \mathrm{ETS}_{4}$ body-weight specific hepatic ETS activity $\mathrm{ETS}_{3} / \mathrm{W}\left(\mu \mathrm{l} \mathrm{O} \mathrm{O}_{2} \mathrm{~min}^{-1} \mathrm{~g}^{-1}\right.$ fish); ETS protein-specific hepatic ETS activity $\mathrm{ETS}_{2} / \mathrm{P}_{2}(\mu \mathrm{l}$ $\mathrm{O}_{2} \min ^{-1} \mathrm{~g}^{-1}$ hepatic protein).

\section{Collection of American Plaice and Liver Tissue Sampling}

About 120 female Hippoglossoides platessoides weighing from 10 to $2,350 \mathrm{~g}$ were collected from St. Margaret's Bay, Nova Scotia (Canada), on 2 occasions in late March 1979. They were captured by otter trawl in 70 to $80 \mathrm{~m}$ of water, approximately mid-way between Horse Island and Shut-in Island (Canadian Hydrographic Service, Decca Chart Chain 7 (Nova Scotia), L(D7)4386. The trawling time was kept short (ca. $10 \mathrm{~min}$ ) to minimize injuries to the fish caused by the dragging process. The fish were maintained alive in a tank of running seawater which was pumped continuously from near the surface.

Upon arrival at the dock, the fish were weighed and measured. Livers were removed, divided into 3 parts, and the portions quickly frozen on dry-ice in separate glass vials. These samples were stored on dry-ice until used in the enzyme assays.

The activities of CYTOX and ETS decreased rapidly when the liver samples or homogenates were allowed to stand at room temperature. Hess and Pope (1953) found that rat tissues stored on dry-ice retained full CYTOX activity for weeks. Ahmed et al. (1976) reported no loss of ETS activity in the diatom Skeletonema costatum and the copepod Calanus pacificus for up to $1 \mathrm{wk}$ if the former was stored below $-60^{\circ} \mathrm{C}$ and the latter below $-20^{\circ} \mathrm{C}$. The effects of dryice freezing and storage of American plaice liver on CYTOX and ETS activities were determined in this study. Freezing per se diminished the CYTOX activity in liver to about $80 \%$ of that for fresh liver but there was no further decrease during the first $3 \mathrm{~d}$ of storage. ETS activity was unaffected by freezing or by storage for at least $15 \mathrm{~d}$. In this study, CYTOX assays were always completed within $3 \mathrm{~d}$ and ETS assays within $10 \mathrm{~d}$ after the livers were frozen.

\section{Cytox Enzyme Preparation}

All operations described in this section were carried out between 0 and $4{ }^{\circ} \mathrm{C}$. 
Frozen livers in vials were allowed to thaw on ice. The obvious portions of the hepatic blood vessels were carefully removed and discarded. The liver was then rinsed with the grinding solution which consisted of potassium phosphate buffer $(0.07 \mathrm{M}, \mathrm{pH} 7.0)$, EDTA ( $1 \mathrm{mM})$ and Triton $\mathrm{X}-100(0.2 \% \mathrm{v} / \mathrm{v})$. The liver was blotted to remove excess moisture and weighed. It was then homogenized for $2 \mathrm{~min}$ in 10 volumes $\left(\mathrm{ml} \mathrm{g}^{-1}\right)$ of the grinding solution in a glass-teflon homogenizing vessel. $\mathrm{A}^{3 / 8}$ inch electric handdrill was used to drive the pestle. The resulting homogenate was sonicated for 2 min using a Braunsonic 1510 sonicator fitted with a semi-micro probe tip operated at $200 \mathrm{~W}$. The sonicated homogenate was centrifuged at $10,000 \times \mathrm{g}$ in a Sorvall RC-5 refrigerated centrifuge for $20 \mathrm{~min}$. After centrifuging, the homogenate was separated into a fatty surface coating, a relatively clear, brown supernatant and a precipitate probably containing blood vessel debris. The supernatant was removed from under the fatty layer with a syringe, transferred to a polycarbonate vial on ice and used as the enzyme preparation.

\section{Cytox Assay}

A substrate solution of freshly reduced cytochrome $\mathrm{C}$ was prepared immediately prior to use by the method of Smith (1955). CYTOX activity was determined spectrophotometrically at $550 \mathrm{~nm}$ as the rate of oxidation of reduced cytochrome C (Smith, 1955).

The reaction mixture consisted of $1.5 \mathrm{ml}$ potassium phosphate buffer $(0.07 \mathrm{M}, \mathrm{pH} 7.0), 1.5 \mathrm{ml}$ reduced cytochrome $\mathrm{C}$ solution $(90 \mu \mathrm{M})$, and $25 \mu$ l enzyme preparation which initiated the oxidation reaction. The blank consisted of $25 \mu l$ of enzyme preparation and $3.0 \mathrm{ml}$ of the potassium phosphate buffer. The reaction was carried out at $25^{\circ} \mathrm{C}$ in a $1 \mathrm{~cm}$ cuvette. The change in extinction at $550 \mathrm{~nm}$ was monitored using a Zeiss spectrophotometer and a Hewlett-Packard strip chart recorder. The reaction was allowed to proceed for about $4 \mathrm{~min}$ and then $\mathrm{K}_{3} \mathrm{Fe}(\mathrm{CN})_{6}(0.1 \mathrm{M} 30 \mu \mathrm{l})$ was added to completely oxidize the cytochrome $\mathrm{C}$.

The final optical density or absorbance of cytochrome $\mathrm{C}_{1}$ after the addition of $\mathrm{K}_{3} \mathrm{Fe}(\mathrm{CN})_{6}$, is given as $O D_{\infty}$ in the calculation. The pseudo first order velocity constant of the reaction, $\mathrm{CYT}_{1}$, was calculated by the following equation:

$C T Y_{1}=\left[\log \left(O D_{t_{1}}-O D_{\infty}\right)-\log \left(O D_{t_{2}}-O D_{\infty}\right)\right] \times 2.303 /$ $\left(t_{2}-t_{1}\right)_{i}$ where $O D_{t_{1}}$ and $O D_{t_{2}}=$ optical densities of the reaction mixture observed at times $t_{1}$ and $t_{2}$ respectively.

Other CYTOX parameters are defined in the list of abbreviations.

\section{ETS Enzyme Preparation}

The procedure was similar to that for the CYTOX preparation. The composition of the ETS grinding solution was potassium phosphate buffer $(0.1 \mathrm{M}, \mathrm{pH} 7.8)$, $\mathrm{MgCl}_{2}(100 \mu \mathrm{M})$, polyvinyl pyrrolidone (PVP-40, ave. mol. wt. 40,$000 ; 37.5 \mu \mathrm{M}), \mathrm{KCN}(2 \mathrm{mM})$ and Triton $\mathrm{X}-100(0.2 \% \mathrm{v} / \mathrm{v})$.

\section{ETS Assay}

The method was similar to that used by Owens and King (1975) with the exception that the reaction was terminated by the addition of $0.5 \mathrm{ml}$ of quench solution (2.4 $\mathrm{N} \mathrm{HCl).} \mathrm{It} \mathrm{was} \mathrm{found} \mathrm{that} \mathrm{the} \mathrm{quench} \mathrm{solution} \mathrm{of}$ $50 \%$ formalin and $50 \% 1 \mathrm{M} \mathrm{H}_{3} \mathrm{PO}_{4}$ used by Owens and King (1975) did not terminate the reaction completely, as indicated by the positive intercepts which appeared on plots of ETS activity versus incubation time. The quench solution of $2.4 \mathrm{~N} \mathrm{HCl}$ used here was able to terminate the reaction completely.

The equation of Packard (1979) for the calculation of ETS activity in phytoplankton or zooplankton was modified for the use of the present assay.

The ETS activity $\left(\mathrm{ETS}_{1}, \mu \mathrm{l} \mathrm{O}_{2} \mathrm{~min}^{-1}\right.$ ) in the reaction mixture was calculated by the following equation:

$\mathrm{ETS}_{1}=(\mathrm{S} \times \mathrm{COD}) /(\mathrm{t} \times \mathrm{l} \times \mathrm{k})$; where $\mathrm{COD}^{\prime}=$ corrected optical density of the reaction mixture; ' $\mathrm{S}$ ' = final volume of the reaction mixture; ' $\mathrm{t}$ ' = incubation time of the reaction mixture in min; ' 1 ' = path length of the spectrophotometer cell; ' $\mathrm{k}$ ' = constant which equals 1.42 for an assay using Triton X-100 as in this assay (Kenner and Ahmed 1975 a).

Other ETS parameters are defined in the list of abbreviations.

\section{Protein Assay}

The protein concentration of the liver homogenate for ETS and CYTOX assay was determined by the fluorescamine reaction (Wiegele et al., 1972; Undefriend et al., 1972), in which proteins were converted to fluorophors and measured fluorometrically on a Zeiss spectrofluorometer with the excitation and emission wavelengths set at 390 and $480 \mathrm{~nm}$ respectively.

\section{RESULTS}

\section{$W_{L}, Q_{L}$ and $W$}

Log $W_{L}$ is significantly related to $\log W(r=0.971, P$ $<0.01$, Table 1). The slope of the regression line does 
Table 1. Hippoglossoides platessoides. Simple regressions of $\log W_{\mathrm{L}}$ and $\log \mathrm{W}_{\mathrm{L}} / \mathrm{W}$ on $\log W$

\begin{tabular}{|c|c|c|c|}
\hline $\begin{array}{l}\text { Dependent } \\
\text { variable }\end{array}$ & $\begin{array}{c}\log \\
\text { intercept }(95 \% \text { C.I. })\end{array}$ & Slope $(95 \%$ C.I.) & $\mathrm{P} n$ \\
\hline $\begin{array}{l}\log W_{L} \\
\log W_{L} / W\end{array}$ & $\begin{array}{l}-2.115(-2.214,-2.015) \\
-2.115(-2.214,-2.015)\end{array}$ & 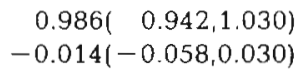 & $\begin{array}{r}0.971,+119 \\
-0.057, \text { ns } 119\end{array}$ \\
\hline \multicolumn{4}{|c|}{$\begin{array}{l}\text { 'C.I.' }=\text { confidence interval; ' } r \text { ' }=\text { correlation coefficient; ' } P \text { ' }=\text { probability that the observed value of } r \text { arises by chance; } \\
\text { ' }{ }^{\prime}=\text { number of fishes } \\
+P<0.01 \text { i ns } P>0.05\end{array}$} \\
\hline
\end{tabular}

not differ significantly from 1 , indicating that $W_{L}$ is linearly related to $W$. Accordingly, there is no relationship between $\log W_{\mathrm{L}} / \mathrm{W}$ and $\log \mathrm{W}$.

\section{Hepatic Cytox and ETS}

Table 2 shows that the logarithms of liver-weight specific, body-weight specific and protein-specific activities of CYTOX and ETS all decrease with increasing $\log \mathrm{W}$ as indicated by the significant $(\mathrm{P}<$ 0.01 , negative values of the computed slopes. Liverweight specific CYTOX $\left(\mathrm{CYT}_{2}\right)$ and ETS $\left(\mathrm{ETS}_{2}\right)$ are functions of $W^{-0.142}$ and $W^{-0.138}$, body-weight specific CYTOX $\left(\mathrm{CYT}_{4}\right)$ and ETS $\left(\mathrm{ETS}_{4}\right)$ are functions of $\mathrm{W}^{-0.169}$ and $W^{-0.102}$, and liver-protein specific CYTOX $\left(C^{-} T_{p}\right)$ and ETS $\left(\right.$ ETS $\left._{p}\right)$ are functions of $W^{-0.103}$ and $W^{-0.121}$. The total hepatic CYTOX $\left(\mathrm{CYT}_{3}\right)$ and ETS $\left(\mathrm{ETS}_{3}\right)$ activities are related to $W^{0.831}$ and $W^{0.898}$ respectively; these values are close to 0.8 as hypothesized. The $95 \%$ confidence interval estimate for the body weight exponent of $\mathrm{CYT}_{3}$ contains 0.8 but the estimate for $\mathrm{ETS}_{3}$ does not.

These relationships between the enzyme parameters and $W$ are quantitatively very similar to those reported for $\dot{V}_{\mathrm{O}_{2}}$ and $\dot{V}_{\mathrm{O}_{2}} / \mathrm{W}$ in fish and mammals (Kleiber, 1941; Krebs, 1950; Vernberg, 1954; Kunkel et al., 1956; MacKinnon, 1972; Parvatheswararao, 1972). The liverweight specific activities $\left(\mathrm{CYT}_{2}\right.$ and $\left.\mathrm{ETS}_{2}\right)$ are dimensionally analogous to $\dot{V}_{\mathrm{O}_{2,}} / \mathrm{W}_{\mathrm{L}}$, the total liver activities

Table 2. Hippoglossoides platessoides. Simple regressions of the logarithms of the various CYTOX and ETS parameters on logW

\begin{tabular}{|c|c|c|c|}
\hline $\begin{array}{l}\text { Enzyme } \\
\text { parameters }\end{array}$ & $\begin{array}{l}\log \\
\text { intercept }(95 \% \text { C.I.) }\end{array}$ & Slope (95\% C.I.) & $\mathrm{P} \quad \mathrm{n}$ \\
\hline $\begin{array}{l}\operatorname{LogCYT}_{2} \\
\operatorname{LogCYT}_{3} \\
\operatorname{LogCYT}_{4} \\
\operatorname{LogCYT}_{\mathrm{P}} \\
\text { LogETS }_{2} \\
\operatorname{LogETS}_{3} \\
\operatorname{LogETS}_{4} \\
\operatorname{LogETS}_{\mathrm{P}}\end{array}$ & $\begin{array}{r}0.834(0.708,0.959) \\
-1.245(-1.417,-1.074) \\
-1.245(-1.417,-1.074) \\
-1.642(-1.806,-1.477) \\
1.433(1.343,1.523) \\
-0.810(-0.950,-0.671) \\
-0.810(-0.950,-0.671) \\
-1.026(-0.118,-0.935)\end{array}$ & $\begin{array}{r}-0.142(-0.196,-0.088) \\
0.831(\quad 0.757, \quad 0.905) \\
-0.169(-0.243,-0.095) \\
-0.103(-0.174,-0.032) \\
-0.138(-0.177,-0.100) \\
0.898(\quad 0.839, \quad 0.957) \\
-0.102(-0.161,-0.043) \\
-0.121(-0.160,-0.082)\end{array}$ & $\begin{array}{r}-0.454,+106 \\
0.910,+106 \\
-0.407,+106 \\
-0.271,+106 \\
-0.587,+101 \\
0.950,+101 \\
-0.326,+101 \\
-0.529,+101\end{array}$ \\
\hline
\end{tabular}

Table 3. Hippoglossoides platessoides. Simple regressions of the logarithms of protein parameters on log W

\begin{tabular}{|c|c|c|c|}
\hline $\begin{array}{c}\text { Protein } \\
\text { parameters }\end{array}$ & $\begin{array}{c}\log \\
\text { intercept (95\% C.I.) }\end{array}$ & Slope $(95 \%$ C.I. $)$ & $r_{1} \quad P \quad n$ \\
\hline $\begin{array}{l}\log P_{2} \\
\log _{3} \\
\log P_{4}\end{array}$ & $\begin{array}{l}-0.525(-0.594,-0.456) \\
-2.604(-2.716,-2.492) \\
-2.604(-2.716,-2.492)\end{array}$ & 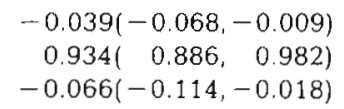 & $\begin{array}{r}-0.247 \cdot 106 \\
0.967+106 \\
-0.259+106\end{array}$ \\
\hline
\end{tabular}


$\left(\mathrm{CYT}_{3}\right.$ and $\mathrm{ETS}_{3}$ ) are analogous to $\dot{\mathrm{O}}_{\mathrm{O}_{2}}$ and the bodyweight-specific activities $\left(\mathrm{CYT}_{4}\right.$ and $\left.\mathrm{ETS}_{4}\right)$ are analogous to $\dot{\mathrm{V}}_{\mathrm{O}_{2}} / \mathrm{W}$.

\section{Hepatic Protein}

Liver-weight specific protein $\left(\mathrm{P}_{2}\right)$ and body weight specific liver protein $\left(\mathrm{P}_{4}\right)$ are related to $\mathrm{W}^{-0.039}(\mathrm{P}<$ $0.05)$ and $W^{-0.066}(P<0.01)$ respectively as shown in Table 3 . They decrease slightly with increasing $W$ as they have negative body weight exponents. Total liver protein $\left(\mathrm{P}_{3}\right)$ is related to $\mathrm{W}^{0.934}(\mathrm{P}<0.01)$. Thus, there is a small but significant $W$-dependency of liver composition, smaller fish having relatively higher proportions of liver protein.

\section{DISCUSSION}

\section{CYTOX, ETS and W}

It is clear from the results that any $W$-dependency of hepatic metabolic processes is not a function of bodyweight specific liver weight $W_{L} / W$. The fact that the protein content of the liver is weakly correlated with $W$ cannot entirely account for the observed relations between $W$ and the various CYTOX and ETS parameters since both protein specific CYTOX (CYTP) and ETS (ETS $)$ activities are rather strongly W-dependent. We conclude that both hepatic CYTOX and ETS appear to be allometrically related to $\mathrm{W}$ in Hippoglossoides platessoides and that this adaptation is brought about by altering the activities of these oxidative enzymes per unit liver mass in such a manner as to mimic quantitatively the relation between whole body $\dot{V}_{\mathrm{O}_{2}}$ (metabolic rate) and W.

Assuming that an organ's content of an oxidative enzyme reflects the maximal ability of the organ to carry out that reaction, it would appear from the values of the exponents relating total hepatic CYTOX $\left(\mathrm{CYT}_{3}\right)$ and $\operatorname{ETS}\left(\mathrm{ETS}_{3}\right)$ to $\mathrm{W}(0.831$ and 0.898 , respectively) that, relative to whole body basal $\mathrm{V}_{\mathrm{O}_{2}}\left(=\mathrm{f}\left(\mathrm{W}^{0.80}\right)\right.$; MacKinnon, 1972), the scope of the liver of the American plaice to perform oxidative metabolism increases somewhat with W. A similar result was obtained in an interspecific study of oxidative enzyme activities of the gastrocnemius muscle of 10 mammalian species (Emmett and Hochachka, 1981). This was interpreted as meaning that large mammals may have a greater scope for aerobic activity than small mammals. Taylor et al. (1981) have demonstrated this for whole-body maximal oxygen consumption rates in mammals.

The relationship between hepatic oxidative enzyme systems (CYTOX and ETS) and W obtained here is quantitatively very similar to that given by Smith (1976) for the liver glycolytic enzyme pyruvate kinase (PYK), the amount of which was shown to be a function of $W$ to the 0.80 power in the American plaice. It was suggested that this value resulted from sampling during the summer when most substrates of liver oxidative metabolism would be channeled through the PyK step. Liver glucose-6-phosphatase was similarly related to $W$ in the plaice but with a higher value for the exponent $(=0.89)$. Somero and Childress (1980), however, have shown for teleost skeletal muscle that larger fish have higher concentrations of PyK and other glycolytic enzymes both per unit weight of tissue and per unit total fish mass. They suggested that this is a result of a similar scaling with $W$ of the energy requirements for anaerobic burst swimming. A similar result was obtained for gastrocnemius muscle glycolytic enzyme activities in 10 species of mammals (Emmett and Hochachka 1981). In contrast, both Somero and Childress (1980), and Emmett and Hochachka (1981) found that skeletal muscle oxidative enzyme activities in fish and mammals were related to $W$ in the same manner as $\dot{\mathrm{V}}_{\mathrm{O}_{2}}$.

\section{CYTOX and ETS as Metabolic Indicators Criteria for Metabolic Indicators}

Physiological and biochemical systems in multicellular organisms must be capable of adaptation on at least 4 time scales. We attempt to illustrate this diagrammatically in Fig. 1. The lines shown represent logarithmic transformations of $\dot{V}_{\mathrm{O}_{2}}=a \mathrm{~W}^{\mathrm{b}}$, where $\mathrm{b}=$ slope of the line; $\log \alpha=$ metabolism for a fish of unit weight. Lines $A$ and $B$ represent the minimum and maximum extents respectively to which the routine level of metabolism (Line E) can adapt. The positions of Lines $A$ and $B$ are determined through natural selection of the genome on the time scale of evolution and are a characteristic of the species. Line $C$ represents the basal (standard, $\vec{V}_{\mathrm{O}_{2, \min }}$ ) and Line $\mathrm{D}$ the maximal (active, $\dot{V}_{\mathrm{O}_{2} \text {, max }}$ ) metabolic rates respectively for fish adapted to the levels of routine metabolism $\left(\dot{V}_{\mathrm{O}_{2}, \mathrm{t} t n}\right)$ represented by Line $\mathrm{E}$. Acclimation can occur by shifting Lines $C, D$, and $E$ up or down within the scope delimited by Lines A and B. A fish must also be able to change its $\dot{V}_{\mathrm{O}_{2} \text {,trn }}$ in the short-term (acute adaptation) as represented by the vertical double arrow labelled 'acute'. A multicellular organism must also adapt on an ontogenetic time scale, as represented by the arrow FG, if the adapting variable is an allometric function of W.

A parameter may serve as a metabolic indicator if it fulfills certain requirements with respect to time scale: 


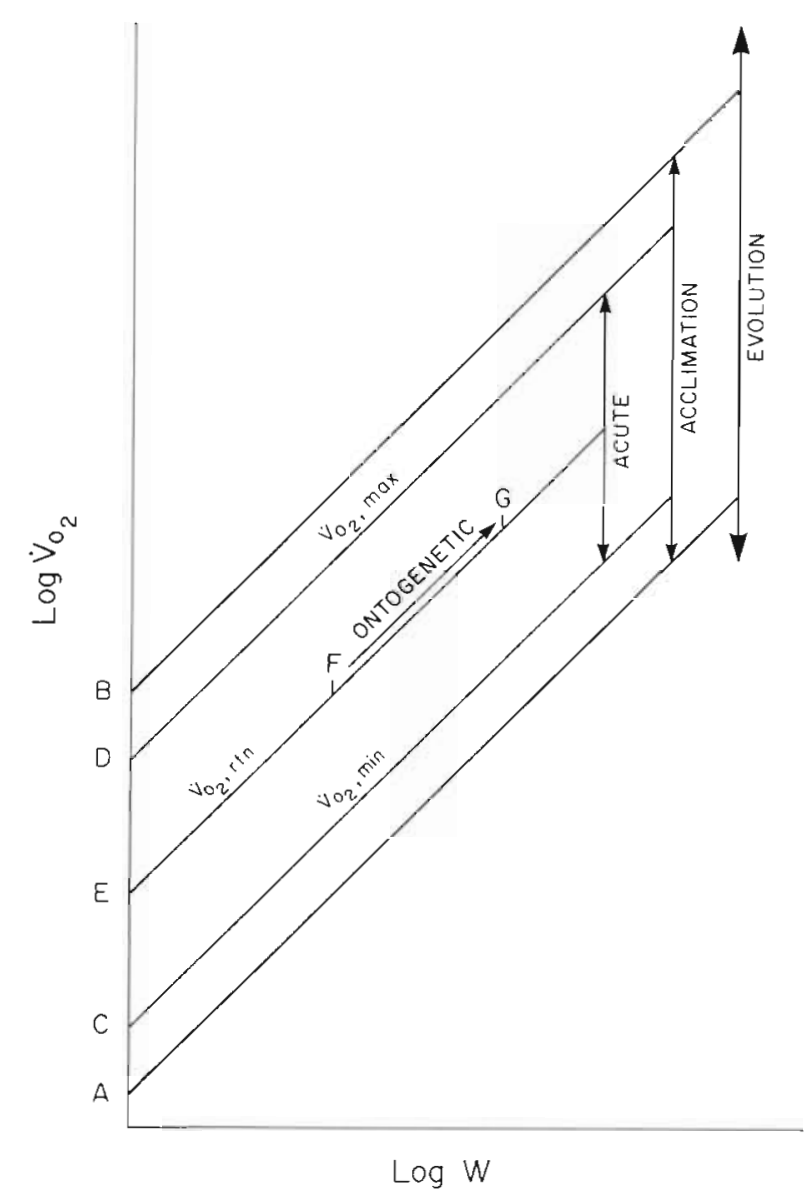

Fig. 1. Diagrammatic representation of the various levels of metabolism (oxygen consumption) discussed in the text

(1) It must not adapt acutely, i. e. within the time taken to collect and stabilize the samples. This is the major problem with oxygen consumption measurements and has led to numerous unsatisfactory compromises. (2) It must be an allometric function of $\mathrm{W}$ with the same value for the exponent as metabolism. (3) It must acclimate to changes in the level of metabolism and this must not occur within the sampling time frame.

In addition to satisfying time scale criteria, an enzymatic metabolic indicator (4) should catalyze the rate limiting reaction for the pathway in which it is involved while not catalyzing the reverse reaction. This point does not seem important here since the ETS and CYTOX reactions are not (so far as we are aware) physiologically reversible and, in the ecological sense, the reverse reactions (oxygen production, energy fixation and carbon reduction) are carried out by various photosynthetic processes. (5) Furthermore, the ETS and CYTOX assays described here are designed to estimate the total tissue content of these enzyme systems. If their activities are indeed related to metabolic rate, then they should most closely reflect $\dot{V}_{\mathrm{O}_{2} \text {, max }}$.
What we wish to measure in an energetics study is $\dot{V}_{\mathrm{O}_{2}, \mathrm{trn}}$. Therefore, in order for CYTOX and ETS to serve as metabolic indicators, both ontogenetic adaptation and acclimation of $\dot{V}_{\mathrm{O}_{2} \text {, tn }}$ must be accompanied by changes in $\vec{V}_{\mathrm{O}_{2} \text {, max }}$ which are either equal to or a simple function of the alteration in the level of $\dot{V}_{\mathrm{O}_{2}, \mathrm{rtn}}$.

\section{Acute Adaptation of CYTOX and ETS}

CYTOX in vertebrate liver mitochondria does not appear to adapt acutely to changes in whole-animal $\mathrm{V}_{\mathrm{O}_{2}}$. Exhaustive swimming $(3 \mathrm{~h})$ in rats produced no change in liver mitochondrial CYTOX activity (Radeva-Domustchieva and Russanov, 1976). However, CYTOX activity in heart mitochondria was elevated by this treatment and remained higher for at least $22 \mathrm{~h}$ (Radeva-Domustchieva and Russanov, 1977). This effect was apparently due to an increase in the permeability of the mitochondrial membrane and should not be a problem in the fully disrupted and solubilized preparations described here. Several components of the ETS system were also shown not to change in rat liver in response to exhaustive swimming (Radeva-Domustchieva and Russanov, 1976).

\section{Ontogenetic Adaptation of CYTOX and ETS}

The allometric dependence of hepatic CYTOX and ETS activities reported here is not unique. Bashamohideen and Parvatheswararao (1976) found that protein specific CYTOX in the liver of Tilapia mossambica was similarly size dependent. In interspecific studies, CYTOX concentrations in the livers of rat, mouse and dog were found to be negatively related to W (Kunkel and Campbell, 1952) and total liver CYTOX of rat, sheep, swine and cattle was very nearly proportional to W to the 0.75 power (Kunkel et al., 1956). ETS activities in freshwater zooplankton (Borgmann, 1978) and Acartia tonsa (Bamstedt, 1980) were significantly related to $W$, larger organisms having lower activities per unit $W$. The total body dehydrogenase activity (closely associated with the electron transport system) in the marine minnow Menidia menidia was related to $W$ in the same way as total body $\dot{V}_{\mathrm{O}_{2}}$ (Curl and Sandberg, 1961).

\section{Acclimation of CYTOX and ETS}

There is a great deal of evidence that CYTOX and ETS acclimate gradually to chronic changes in the level of metabolism. CYTOX and other cytochromes of the rat heart and liver inner mitochondial membrane turned over with a half-life of 5 to $6 \mathrm{~d}$ (Rabinowitz and 
Zak, 1975). During exercise training in man, wholebody $\dot{V}_{\mathrm{O}_{2}, \max }$ and skeletal muscle CYTOX activity increased gradually and were significantly different from the pre-training level only after 3 wk (Henriksson and Reitman, 1977). Tipton and Nixon (1946) found in rat liver that the change in hepatic CYTOX activity lagged about $4 \mathrm{~d}$ behind the change in $\mathrm{V}_{\mathrm{O}_{2} \mathrm{~L}} / \mathrm{W}_{\mathrm{L}}$ following thyrotrophic hormone administration. Bamstedt (1980) found that ETS in zooplankton acclimated to a change in the physical environment only after 3 to $4 \mathrm{~d}$.

There is also evidence that CYTOX level is established in an adaptive fashion by the metabolic needs of the animal or organ. Rat liver CYTOX concentration increases with the elevation in metabolism resulting from thyrotoxicosis (Tipton et al., 1946; Tipton and Nixon, 1946) and decreases in protein deficiency (Williams et al., 1966). Nishiki et al. (1978) have shown that thyroxine elicits an increased work rate and $\dot{\mathrm{V}}_{\mathrm{O}_{2}}$ in the isolated, perfused rat heart and that this is associated with higher contents both of cytochromes per mitochondrion and of mitochondrial protein per unit weight of myocardium. An energy restricted diet had a similar effect on all the components of the cytochrome chain (Ramamadhan and Keplay, 1977), while CYTOX concentrations were markedly increased in fat deficiency associated with increased metabolic rate (Kunkel and Williams, 1951). Following denervation of the rat gastrocnemius muscle, CYTOX activity and oxygen consumption of the tissue decreased progressively together (Humoller et al., 1953). Like other enzymes concerned with energy liberation, CYTOX concentration in fish exhibited compensatory temperature acclimation (Freed, 1965; Caldwell, 1969; Hazel and Prosser, 1970). CYTOX activity and oxygen consumption increased together during osmotic stress in fish (Bashamohideen and Parvatheswararao, 1972). A marked decrease in both heart and skeletal muscle CYTOX concentration occurred in the turtle Pseudemys scripta elegans following prolonged oxygen depletion induced by a maintained underwater dive (Simon and Robin, 1970). Increased muscle CYTOX concentration was associated with increased muscle $\mathrm{O}_{2}$ consumption in mammals subjected to increased physical exercise (Holloszy, 1967; Henriksson and Reitman, 1977). CYTOX and ETS activities show changes that are directly related to seasonal variations in metabolism in natural populations of the American plaice and winter flounder (Chong and Smith, 1982 a) and to ration and metabolic levels in rainbow trout (Chong and Smith, $1982 \mathrm{~b}$ ). Thus CYTOX and ETS are under environmental, hormonal and dietary control. The allometric dependence of CYTOX and ETS activities on $\mathrm{W}$ is probably due to a similar adaptive response to the general level of metabolism

\section{Rate-Limiting Steps in Electron Transport}

Robin et al. (1970) and Simon and Robin (1971) proposed that the CYTOX reaction is the rate-limiting step in electron transport because of the apparent dependency of substrate $\left(\mathrm{O}_{2}\right)$ utilization on enzyme level. The ETS assay using INT reduction is based on the measurement of maximal electron flow from substrates to oxygen in both mitochondrial and mic rosomal electron transport. The site of INT reduction in the mitochondrial electron transport system appears to be the step of the oxidation of the coenzyme $Q$-cytochrome b complex (Lester and Smith, 1961; Chance et al., 1967; Gahan and Kalina, 1968; Kalina and Palmer, 1968; Kenner and Ahmed, 1975 a). Chance et al. (1955) suggested that this is the rate-limiting step for mitochondrial electron transport. Thus the ETS activity assayed may be a function of the maximal potential rate of electron transport. However, Klingenberg (1968) suggested there is no true rate-limiting step in electron transport. The similar allometric relationships of both hepatic ETS and CYTOX to $W$ in the American plaice lend support to Fitch and Chaikoff's (1960) proposal that alteration in enzymatic activities in a metabolic pathway may be broad in extent, rather than involving only one key, rate-limiting enzyme. Cytochrome $\mathrm{C}$ concentration in mammals also varied in parallel with CYTOX, both having similar relations to W (Rosenthal and Drabkin, 1943).

The definitive studies in this regard, however, are probably those of Erecinska and co-workers. For example, Nishiki et al. (1978) showed for the mammalian heart that thyroxine elicits increased work and oxygen consumption rates as well as an increase both in mitochondrial mass per unit myocardial weight and an increase in cytochrome content per mitochondrion. Moreover, the ratio of cytochrome $c$ to cytochrome $\mathrm{aa}_{3}$ remained the same whatever the thyroid state indicating that the respiratory chain responds as a unit. They also demonstrate that the free energy relationships between the mitochondrial redox reactions and ATP synthesis indicate that the first 2 sites of oxidative phosphorylation remain near equilibrium in various thyroid states, a result strongly suggestive of the regulation of respiration occurring at the cytochrome oxidase-oxygen reaction.

\section{CYTOX and ETS and their Relationship to $\dot{V}_{\mathrm{O}_{2}, \max }$ and $\dot{V}_{\mathrm{O}_{2}, \mathrm{rnn}}$}

The fact that both total liver CYTOX and ETS have been shown here to be functions of $W$ to about the same power as $\dot{\mathrm{V}}_{\mathrm{O}_{2}}$ implies that Lines $\mathrm{D}$ and $\mathrm{E}$ in Fig. 1 are nearly parallel, assuming that total liver CYTOX 
and ETS are direct functions of $\dot{V}_{O_{2} \text { max }}$. Although we have no information on whether acclimation of $\dot{V}_{\mathrm{O}_{2, \text { rn }}}$ in a fish of a given size is likely to be accompanied by an

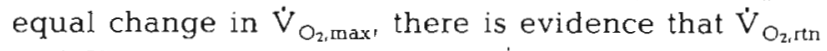
and ETS activity are related by a constant ratio in phytoplankton (Kenner and Ahmed, 1975 b), zooplankton (Owens and King, 1975; King and Packard, 1975; Borgmann, 1978) and marine bacteria (Christensen et al., 1980). Exponential relationships between CYTOX concentration and body or organ-weight specific $\dot{\mathrm{V}}_{\mathrm{O}_{2}}$ have been demonstrated in various vertebrate species (Simon and Robin, 1971) while in Menidia dehydrogenase activity was linearly related to $\dot{\mathrm{V}}_{\mathrm{O}_{2}}$. It is likely that significant relationships between respiration and CYTOX and ETS activities will exist for fishes generally. If these relationships can be shown to be precise, then either CYTOX or ETS activity could serve as a metabolic indicator under equilibrium conditions.

\section{LITERATURE CITED}

Ahmed, S. I., Kenner, R. A., King, F. D. (1976). Preservation of enzymatic activity in marine plankton by low-temperature freezing. Mar. Chem. 4: 133-139

Bamstedt, U. (1980). ETS activity as an estimator of respiratory rate of zooplankton populations. The significance of variations in environmental factors. J. exp. mar. Biol. Ecol. 42: $267-283$

Bashamohideen, M., Parvtheswararao, V. (1972). Adaptations to osmotic stress in the fresh-water euryhaline teleost Tilapia mossambica. IV. Changes in blood glucose, liver glycogen and muscle glycogen levels. Mar. Biol. 16: 68-74

Bashamohideen, M., Parvatheswararao, V. (1976). Sizemetabolism relation in animals. A critical evaluation. Zool. Anz., Jena 196: 333-337

Borgmann, U. (1978). The effect of temperature and body size on electron transport system activity in freshwater zooplankton. Can. J. Zool. 56: 634-642

Caldwell, R. S. (1969). Thermal compensation of respiratory enzymes in tissues of the goldfish (Carassius auratus L.). Comp. Biochem. Physiol. 31: 79-93

Chance, B., Ernster, L., Garland, P. B., Lee, C. P., Light, P. A., Ohnishi, T., Ragan, C. I., Wong, D. (1967). Flavoproteins of the mitochondrial respiratory chain. Proc. natn. Acad. Sci. U.S.A. 57: 1498-1505

Chance, B., Williams, G. R., Holmes, W. F., Higgins, J. (1955). Respiratory enzymes in oxidative phosphorylation. J. biol. Chem. 217: 439-451

Chong, C. K., Smith, J. C. (1982a). Variations in the hepatic cytochrome oxidase and electron transport system activities of American plaice and winter flounder due to season, sex and state of maturity. (in preparation)

Chong, C. K., Smith, J. C. (1982b). Measures of key enzyme activities of the respiratory chain, glycolysis and pentose phosphate pathway in relation to ration, growth and metabolism in rainbow trout, Salmo gairdneri. (in preparation)

Christensen, J. P., Owens, T G., Devol, A. H., Packard, T. T. (1980). Respiration and physiological state in marine bacteria. Mar. Biol. 55: 267-276
Christensen, J. P., Packard, T T. (1976). Oxygen utilization and plankton metabolism in a Washington fjord. Estuar. coast. mar Sci. 4: 339-347

Curl, H. C., Jr., Sandberg, J. (1961). The measurement of dehydrogenase activity in marine organisms. J. mar. Res. 19: $123-138$

Devol, A. H., Packard, T. T. (1978). Seasonal changes in respiratory enzyme activity and production in Lake Washington microplankton. Limnol. Oceanogr. 23: 104-111

Emmett, B., Hochachka, P. W. (1981). Scaling of oxidative and glycolytic enzymes in mammals. Respir. Physiol. 45: 261-272

Fitch, W. M. Chaikoff, I. L. (1960). Extent and patterns of enzyme activities in livers of normal rats fed diets high in glucose and fructose. J. biol. Chem. 235: 554-557

Freed, J. (1965). Changes in activity of cytochrome oxidase during adaptation of goldfish to different temperatures. Comp. Biochem. Physiol. 14: 651-659

Gahan, P. H., Kalina, M. (1968). The use of tetrazolium salts in the histochemical demonstration of succinic dehydrogenase activity in plant tissues. Histochemie $14: 81-88$

Hazel, J., Prosser, C. L. (1970). Interpretation of inverse acclimation to temperature. Z. vergl. Physiol. 67: 217-228

Henriksson, J., Reitman, J. S. (1977). Time course of changes in human skeletal muscle succinate dehydrogenase and cytochrome oxidase activities and maximal oxygen uptake with physical activity and inactivity. Acta Physiol. Scand. 99: 91-97

Hess, H. H., Pope, A. J. (1953). Ultramicrospectrophotometric determination of cytochrome oxidase for quantitative histochemistry. J. biol. Chem. 204: 295-306

Holloszy, J. O. (1967). Biochemical adaptation in muscle effects of exercise on mitochondrial oxygen uptake and the respiratory enzyme activity in skeletal muscle. J. biol. Chem. 242: 2278-2282

Humoller, E. L., Hatch, D., Ware, F., McIntyre, A. R. (1953). Effects of immobilization on oxygen uptake of skeletal muscle. Proc. Soc. exp. Biol. Med. 84: 380-383

Jansky, L. (1961). Total cytochrome oxidase activity and its relation to basal and maximal metabolism. Nature, Lond. 189: 921-922

Kalina, M., Palmer, J. M. (1968\}. The reduction of tetrazolium salts by plant mitochondria. Histochemie 14: 366-374

Kenner, R. A., Ahmed, S. I. (1975a). Measurements of electron transport activities in marine phytoplankton. Mar. Biol. 33: 119-127

Kenner, R. A., Ahmed, S. I. (1975b). Correlation between oxygen utilization and electron transport activity in marine phytoplankton. Mar. Biol. 33: 129-133

King, F. D., Devol, A. H., Packard, T T. (1978). Plankton metabolic activity in the eastern tropical North Pacific. Deep Sea Res. 25: 689-704

King, F. D., Packard, T. T. (1975). Respiration and the activity of the respiratory electron transport system in marine zooplankton. Limnol. Oceanogr. 20: 849-854

Kleiber, M. (1941). Body size and metabolism of liver slices in vitro. Proc. Soc. exp. Biol. Med. 48: 419-423

Klingenberg, M. (1968). The respiratory chain. In: Singer, T P. (ed.) Biological oxidations. Interscience, New York, pp. 3-54

Krebs, H. A. (1950). Body size and tissue respiration. Biochim. Biophys. Acta 4: 249-269

Kunkel, H. O., Williams, J. N., Jr. (1951). The effect of fat deficiency upon enzyme activity in the rat. J. biol. Chem. 189: 755-761

Kunkel, H. O., Campbell, J. E., Jr. (1952). Tissue cytochrome 
oxidase activity and body weight. J. biol. Chem. 198: 229-236

Kunkel, H. O., Spalding, J. F., deFranciscis, G., Futrell, M. F. (1956). Cytochrome oxidase and body weight in rats and three species of large animals. Am. J. Physiol. 186: 203-206

Lester, R. L., Smith, A. L. (1961). Studies on the electron transport system. XXVIII. The mode of reduction of tetrazolium salts by beef heart mitochondria; role of coenzyme $Q$ and other lipids. Biochim. Biophys. Acta 47: $475-496$

Mackinnon, J. C. (1972). Production dynamics of a marine flatfish population. Ph.D. thesis, Dalhousie University, Halifax, Nova Scotia

Nishiki, K., Erecinska, M., Wilson, D. F., Cooper, S. (1978). Evaluation of oxidative phosphorylation in hearts from euthyroid, hypothyroid, and hyperthyroid rats. Am. J. Physiol. 235 (5): C212-C219

Owens, T. G., King, F. D. (1975). The measurement of respiratory electron transport-system activity in marine zooplankton. Mar. Biol. 30: 27-36

Packard, T. T. (1971). The measurement of electron transport activity in marine phytoplankton. J. mar. Res. 29: 235-244

Packard, T. T. (1979). Comments on the standardization of the ETS assay. CUEA (Coastal Upwelling Ecosystems Analysis) Newsletter 8: 54-56

Paloheimo, J. E., Dickie, L. M. (1966). Food and growth of fishes. II. Effects of food and temperature on the relation between metabolism and body weight. J. Fish. Res. Bd Can. 23: 869-908

Parvatheswararao, V. (1972). Assessment of metabolic compensation to thermal stress in poikilotherms - A critical evaluation. J. scient. ind. Res. 31: 273-278

Rabinowitz, M., Zak, R. (1975). Mitochondria and cardiac hypertrophy. Circulation Res. 36: 367-374

Radeva-Domustchieva, D., Russanov, E. (1976). Effect of exhaustive swimming on the oxidative phosphorylation and the activity of some enzymes in the rat liver mitochondria. Acta Physiol. Pharmacol. Bulgarica 2: 72-77

Radeva-Domustchieva, D., Russanov, E. (1977). Effect of single exhaustive swimming on mitochondrial enzyme activities in rat myocardium. Acta Physiol. Pharmacol. Bulgarica 3: 49-55

Ramamadham, M., Keplay, S. S. (1977). Rat liver mitochondrial cytochrome $\mathrm{C}$ oxidase and cytochromes in experimental protein-energy malnutrition. Nutr. Metabol. 22: 73-81

Robin, E. D., Simon, L. M., Theodore, J. (1970). Biochemical adaptations subserving prolonged diving in aquatic mammals. In: Poulter, T. C. (ed.) Proceedings of the seventh annual conference on biological sonar and diving mammals. Stanford Research Institute, Menlo Park, Calif., pp. $105-114$
Rosenthal, O., Drabkin, D. L. (1943). Cytochrome C, cytochrome oxidase and body size. Fed. Proc. 2: 69

Simon, L. M., Robin, E. D. (1970). Changes in heart and skeletal muscle cytochrome oxidase activity during anaerobiosis in the freshwater turtle Pseudemys scripta elegans. Comp. Biochem. Physiol. 37: 437-443

Simon, L. M., Robin, E. D. (1971). Relationship of cytochrome oxidase activity to vertebrate total and organ oxygen consumption. Int. J. Biochem. 2: 569-573

Smith, J. C. (1976). Body weight and the activities of pyruvate kinase, glucose-6-phosphatase and lactate dehydrogenase in the liver of the American plaice. Hippoglossoides platessoides. Comp. Biochem. Physiol. 53 B: 277-282

Smith, L. (1955). Spectrophotometric assay of cytochrome-C oxidase. In: Glick, D. (ed.) Methods of biochemical analysis. Interscience, New York, pp. 427-434

Somero, G. N., Childress, J. J. (1980). A violation of the metabolism-size scaling paradigm: activities of glycolytic enzymes in muscle increase in larger-size fish. Physiol. Zool. 53 (3): 322-337

Taylor, C. R., Maloiy, G. M. O., Weibel, E. R., Langman, V. A., Kamau, J. M. Z., Seeheman, J. H., Heglung, N. C. (1981). Design of the mammalian respiratory system. III. Scaling maximum aerobic capacity to body mass: wild and domestic mammals. Respir. Physiol. 44: 25-37

Tipton, S. R., Leath, M. J., Tipton, J. H., Nixon, W. L. (1946). The effects of feeding thyroid substance and of adrenalectomy on the activities of succinoxidase and cytochrome oxidase in the liver tissue of rats. Am. J. Physiol. 145: 693-698

Tipton, S. R., Nixon, W. L. (1946). The effect of thiouracil on the succinoxidase and cytochrome oxidase of rat liver. Endocrinology 39: 300-306

Udenfriend, S., Stein, S., Bohlen, P., Dairman, W., Leimgruber, W., Wiegele, M. (1972). Fluorescamine: a reagent for assay of amino acids, peptides, proteins, and primary amines in the picomole range. Science, N.Y. 17: 871-872

Vernberg, F. J. (1954). The respiratory metabolism of tissues of marine teleosts in relation to activity and body size. Biol. Bull. mar. biol. Lab., Woods Hole 106: 360-370

Wiegele, M., DeBernardo, S. L., Tengi, J. P., Leimgruber, W. (1972). A novel reagent for the fluorometric assay of primary amines. J. Am. Chem. Soc. 94: 5927-5928

Williams, J. N., Jr., Jacob, R. M., Hurlebaus, A. J. (1966). Correlation of liver cytochrome oxidase activity with mitochondrial cytochrome oxidase and phospholipid concentrations in protein-deficient rats. J. Nutr. 90; 81-85

Winberg, C. G. (1956). [Rate of metabolism and food requirement of fishes.] Belorusskovo Nauchnye Trudy Belorusskovo Gosudarstvennovo Universiteta imeni V. I. Lenina, Minsk (Transl. Fish. Res. Bd Can., No. 194) 